\title{
Peningkatan Ekonomi Masyarakat Dengan Berwirausaha Rempeyek Bayam Di Desa Cigelam Kecamatan Ciruas Kabupaten Serang
}

\author{
Andari $^{1}$, Dian Maulita ${ }^{2}$, Denny Putri Hapsari ${ }^{3}$ \\ ${ }^{1}$ Manajemen, Universitas Serang Raya \\ ${ }^{2}$ Akuntansi, Universitas Serang Raya \\ ${ }^{3}$ Akuntansi, Universitas Serang Raya
}

Email: $\underline{1 \text { andaridharmawan@gmail.com, 2maulita.dian@gmail.com, } 3 \text { denny.putri@rocketmail.com }}$

\begin{abstract}
Abstrak
Kemiskinan merupakan salah satu masalah yang dihadapi dalam perekonomian Nasional maupun perekonomian daerah. Desa Cigelam merupakan daerah yang mayoritas keadaan ekonomi masyarakatnya masih ditingkat menengah kebawah dengan mata pencaharian sebagai petani. Tujuan dari kegiatan pengabdian ini adalah (1) Memberikan pengetahuan, dan keterampilan untuk menjadi pelaku usaha (2) Menumbuhkembangkan jiwa berwirausaha dengan memanfaatkan tanaman bayam menjadi rempeyek bayam (3) Membentuk usaha dagang rempeyek bayam. Metode pelaksanaan kegiatan terdiri dari beberapa tahapan yakni sebagai berikut: (1) Perencanaan dan persiapan; (2) Pelaksanaan; (3) Evaluasi. Dengan diadakannya seminar kewirausahaan serta pelatihan pembuatan rempeyek bayam bagi masyarakat Desa Cigelam diharapkan dapat menciptakan lapangan pekerjaan, meningkatkan keterampilan masyarakat, meningkatkan kemampuan berwirausaha serta meningkatkan pendapatan masyarakat dengan memanfaatkan potensi desa.
\end{abstract}

Kata Kunci: Peningkatan Ekonomi, Wirausaha

\begin{abstract}
Poverty is one of the problems faced in the national economy and regional economy. Cigelam village is an area where the majority of the economic situation of its people is still in the middle to lower level with livelihoods as farmers. The objectives of this service activity are (1) Providing knowledge, and skills to become a business actor (2) Growing the spirit of entrepreneurship by utilizing spinach plants into spinach chips

(3) Establishing spinach business. The method of implementing the activity consists of several stages, namely as follows: (1) Planning and preparation; (2) Implementation; (3) Evaluation. With the holding of entrepreneurship seminars as well as training in making spinach chips for the villagers of Cigelam, it is hoped that they can create jobs, improve community skills, improve entrepreneurship skills and increase community income by utilizing village potential.
\end{abstract}

Keywords : Increasing Economy, Entrepreneurship

\section{PENDAHULUAN}

Kemiskinan merupakan salah satu masalah dalam perekonomian yang harus kita pecahkan bersama. Saat ini pemerintah terus menggencarkan Gerakan Kewirausahaan untuk mengatasi permasalahan kemiskinan dan pengangguran. "Entrepreneurship" adalah terjemahan dari istilah Kewirausahaan yang artinya adalah sebagai "the backbone of economy" syaraf pusat perekonomian atau pengendali perekonomian suatu bangsa. Tidak hanya itu saja usaha kecil pun memiliki kontribusi yang cukup besar dalam mengatasi ketenagakerjaan suatu bangsa. 
Kabupaten Serang menempati posisi ketiga tingkat kemiskinan dari delapan kabupaten dan kota di Provinsi Banten. Berdasarkan data BPS Kabupaten Serang Penduduk miskin (penduduk yang berada dibawah Garis Kemiskinan) di Kabupaten Serang pada tahun 2017 berjumlah 69,11 ribu orang atau $4,63 \%$ persen dari total penduduk, bertambah sebanyak 1.190 orang $(0,05$ persen $)$ jika dibandingkan dengan penduduk miskin pada tahun 2016 yang jumlahnya 67,92 ribu orang (4,58 persen).

Desa cigelam adalah salah satu desa yang terletak di kecamatan ciruas kabupaten serang provinsi banten. Desa cigelam memiliki luas wilayah 391,3 Ha dan jarak dari pusat pemerintahan kabupaten $17 \mathrm{Km}$. Desa cigelam terletak di ujung wilayah kecamatan ciruas, dengan batas - batas wilayah sebagai berikut:

1. Sebelah utara berbatasan dengan sebelah utara kecamatan pontang

2. Sebelah barat berbatasan dengan kecamatan kasemen

3. Sebelah selatan berbatasan dengan desa pamong

4. Sebelah timur di batasi oleh desa penggalang kecamatan ciruas

Desa cigelam memiliki lima kampung terdiri dari kp.cigelam, kp. Cikele, kp. Cigalor, kp. Kesampangan dan kp. Kagulon.

Setiap kampung dibatasi dengan sawah atau di kelilingi oleh persawahan hanya satu akses jalan yang saling menghubungkan antar kampung. Berdasarkan letak wilayahnya, desa Cigelam merupakan wilayah dengan potensial hasil buminya adalah pertanian (sawah/ladang) dengan persentase produktif $100 \%$. Lebih dari sebagian wilayahnya merupakan persawahan yang luasnya hingga ratusan hektar. Sehingga pendapatan asli daerah pemerintah desa Cigelam adalah hasil pertanian (sawah, dengan penyebutan panen). Mayoritas keadaan ekonomi masyarakat masih ditingkat menengah ke bawah. Tidak sedikit penduduk Desa Cigelam yang bekerja menjadi TKI
(Tenaga Kerja Indonesia) dan TKW (Tenaga Kerja Wanita) ke luar negeri untuk memenuhi kebutuhan hidupnya. Mereka rela berpisah dari keluarga mereka supaya memiliki penghasilan dan meningkatkan perekonomian keluarga.

Desa Cigelam memiliki potensi yang baik untuk berwirausaha selain memiliki lahan kosong yang dapat dimanfaatkan untuk bercocok tanam tanaman bayam, dan juga diuntungkan dengan lokasi desa yang tidak jauh dengan kota. Sehingga memudahkan pelaku usaha tersebut untuk menjual hasil produknya dengan nilai jual yang lebih tinggi. Namun rendahnya minat masyarakat untuk menjadi pelaku usaha mendorong kami melaksanakan pengabdian masyarakat untuk membangun jiwa wirausaha dengan memanfaatkan potensi desa secara kreatif dan inovatif. Atas dasar hal tersebutlah solusi untuk permasalahan peningkatan perekonomian dengan menjadi pelaku usaha dengan memanfaatkan potensi desa yaitu tanaman bayam menjadi produk yang inovatif.

Tujuan dari kegiatan pengabdian masyarakat ini adalah (1) Memberikan pengetahuan, dan keterampilan untuk menjadi pelaku usaha (2) Menumbuhkembangkan jiwa berwirausaha dengan memanfaatkan tanaman bayam menjadi rempeyek bayam sehingga dapat menumbuhkembangkan ekonomi produktif. (3) Membentuk usaha dagang rempeyek bayam.

\section{METODE PELAKSANAAN}

Metode pelaksanaan kegiatan terdiri dari beberapa tahapan yakni sebagai berikut: (1) Perencanaan dan persiapan; (2) Pelaksanaan; (3) Evaluasi

\section{Perencanaan dan Persiapan}

Tahap persiapan dan perencanaan dimulai dari melakukan survey dan wawancara kepada masyarakat Desa untuk mendapatkan informasi-informasi terkait keadaan ekonomi, dan potensi desa. Berdasarkan hasil survey diketahui masyarakat desa cigelam memiliki 
hasil pertanian yaitu tanaman bayam, yang hasil panennya dijual kepada para konsumen langsung dan pedagang pasar dengan harga yang sangat murah. Selain itu teridentifikasi pula permasalahan yang dialami warga Desa Cigelam yaitu sebagai berikut:

1. Mayoritas keadaan ekonomi masyarakat masih ditingkat menengah ke bawah.

2. Warga Desa Cigelam khususnya ibu rumah tangga belum dapat memanfaatkan sisa waktu untuk kegiatan produktif.

3. Masyarakat yang belum memiliki penghasilan/ pengangguran.

4. Tingkat kreativitas dan inovasi masyarakat masih rendah

5. Masyarakat masih memiliki mental yang rendah untuk memulai suatu usaha

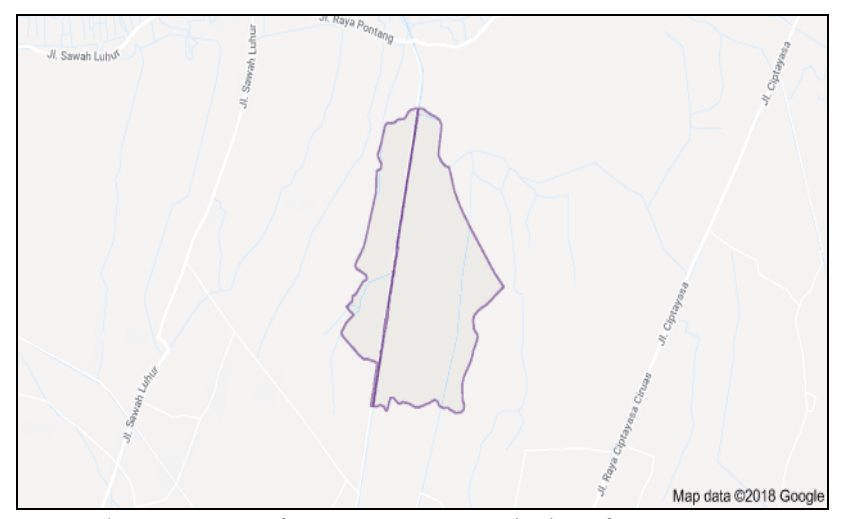

Gambar 1. Kegiatan Survey lokasi pengabdian

Atas hasil analisis survey dilakukan koordinasi dengan pemerintah setempat baik RT, RW dan Kelurahan untuk merencanakan kegiatan selanjutnya yaitu memberikan pengetahuan berwirausaha dalam bentuk seminar dan pelatihan pembuatan produk kreatif yaitu mengolah tanaman bayam menjadi rempeyek bayam.

\section{Pelaksanaan}

Pelaksanaan kegiatan menggunakan metode Entrepereneurship Education yang memberikan pendidikan berwirausaha bagi masyarakat, dengan menggunakan beberapa tahapan yaitu:

1. Tahap Observasi, melakukan pengamatan secara langsung ke lahan masyarakat di Desa Cigelam untuk melihat tanaman bayam.

2. Wawancara, melakukan pertemuan dengan masyarakat sekitar yang memiliki hasil tanaman bayam dan Ibu kepala Desa Cigelam.

3. Mengadakan kegiatan seminar wirausaha bagi masyarakat Desa Cigelam Kecamatan Ciruas Kabupaten Serang.

4. Pelatihan membuat produk dari tanaman bayam menjadi rempeyek bayam.

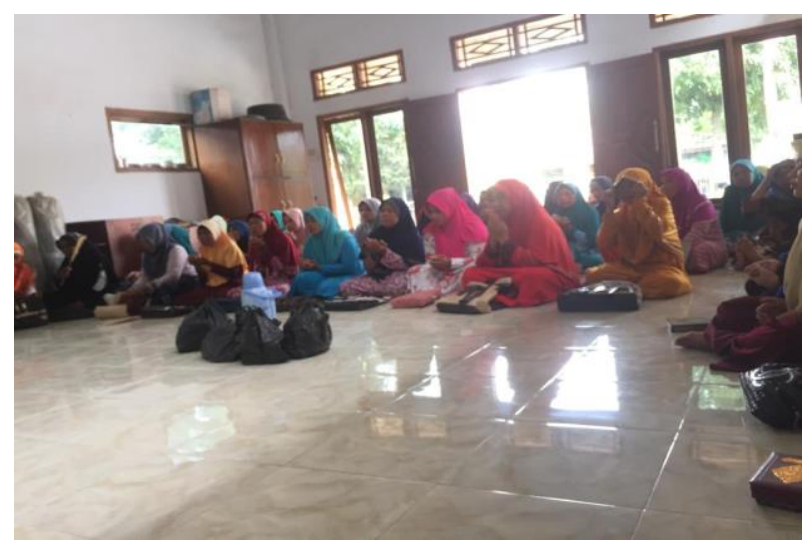

Gambar 2. Kegiatan wawancara dengan warga Desa Cigelam

\section{HASIL DAN PEMBAHASAN}

Kegiatan Seminar wirausaha dilaksanakan di balai desa dengan dihadiri oleh 50 orang warga Desa Cigelam dan unsur pemerintah desa seperti Ketua RT, RW dan Kepala Desa Cigelam. Kegiatan ini mendapatkan banyak perhatian dan dukungan dari masyarakat dan pemerintah setempat, dimulai dari pemberian ijin pelaksanaan kegiatan di kantor Balai Desa dan mendorong masyarakatnya untuk mengikuti acara seminar 
sampai selesai. Hal ini menunjukkan bahwa tingginya minat masyarakat untuk meningkatkan perekonomiannya dengan menjadi pelaku usaha/berwirausaha.

Menurut Indah,dkk (2012) jiwa kewirausahaan mampu memberikan manfaat bagi masyarakat baik manfaat finansial maupun non finansial. Manfaat finansial dari kewirausahaan dapat berupa kemandirian ekonomi yang diperoleh dalam menjalankan usaha. Sedangkan manfaat non finansial berupa terbentuknya mental yang tangguh dan pantang menyerah dalam menghadapai permasalahan hidup.

Teori tentang wirausaha disampaikan kepada peserta agar masyarakat lebih memahami kewirausahaan. Berikut materimateri yang disampaikan:

1. Pengertian kewiruasahaan

2. Kepribadian wirausaha

3. Ciri wirausaha berhasil

4. Faktor-faktor Kunci dalam Pengelolaan Potensi Desa secara Inovatif

Kewirausahaan merupakan faktor penting dalam meningkatkan perekonomian masyarakat. Definisi kewirausahaan menekankan empat aspek dasar menjadi seorang pengusaha: 1) Melibatkan proses penciptaan dan menciptakan suatu nilai baru 2) Menuntut sejumlah waktu dan upaya yang dibutuhkan 3) Melibatkan seseorang menjadi pengusaha, penghargaan yang paling penting adalah kebebasan, lalu kepuasan pribadi, 4) Pengusaha akan merespon dan menciptakan perubahan melalui tindakan. Tindakan kewirausahaan menyatu pada perilaku sebagai bentuk tanggapan atas keputusan yang didasarkan pada pertimbangan ketidakpastian mengenai peluang untuk mendapatkan keuntungan. (Rosmiati dkk, 2015).

Seorang wirausaha dituntut untuk dapat melihat peluang pasar, selain itu kreativitas dan inovasi pun merupakan faktor penting. Dengan diadakannya seminar wirausaha bagi masyarakat desa cigelam diharapkan masyarakat dapat membentuk usaha baik secara mandiri atau kelompok dengan tujuan sebagai berikut:

a. Memberdayakan masyarakat Desa Cigelam

Pemberdayaan masyarakat ini bertujuan untuk memperbaiki pendapatan, memperbaiki usaha, memperbaiki kehidupan.

b. Mengurangi tingkat pengangguran dan kemiskinan

c. Memanfaatkan potensi desa yaitu tanaman bayam untuk diolah menjadi suatu produk yang memiliki nilai jual lebih tinggi.

d. Meningkatkan perekonomian masyarakat

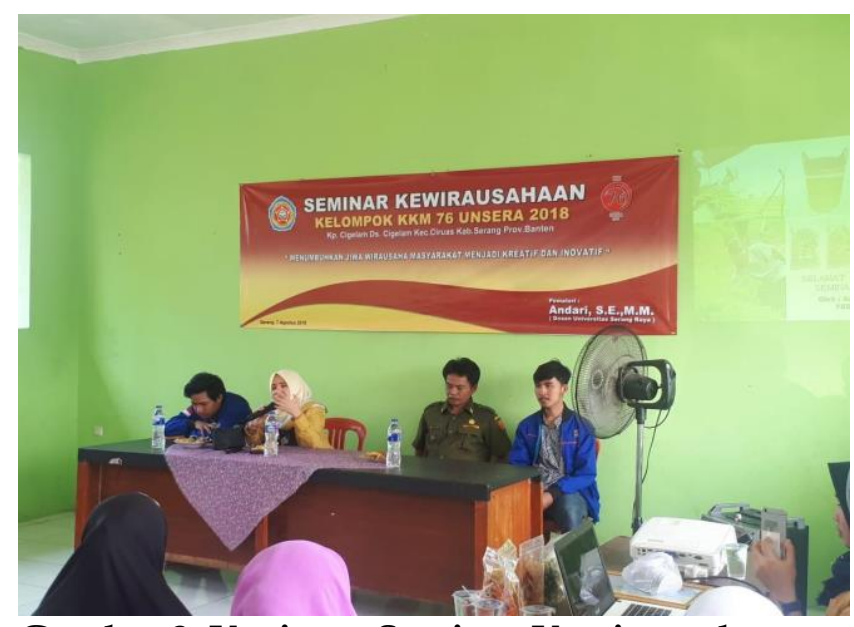

Gambar 3. Kegiatan Seminar Kewirausahaan

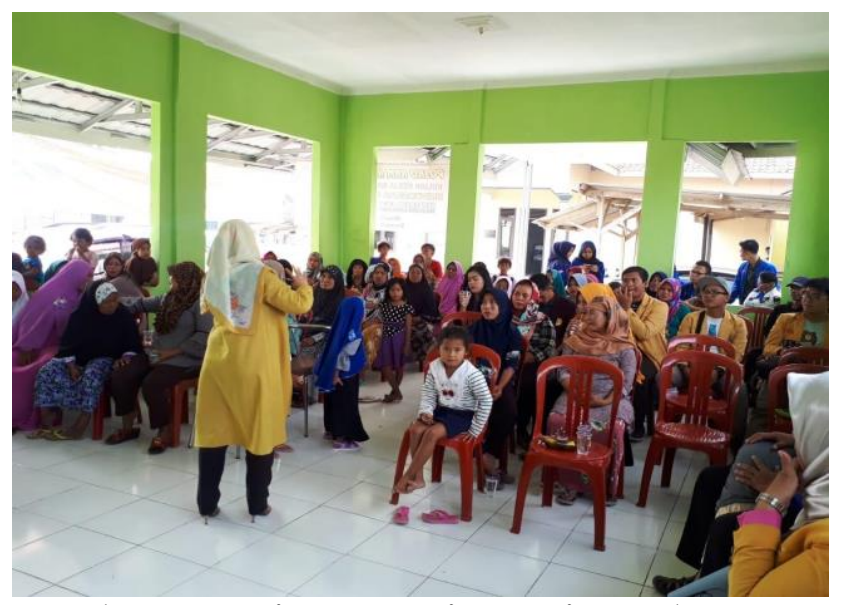

Gambar 4. Kegiatan Seminar Wirausaha

\section{Pelatihan Wirausaha Rempeyek Bayam}

Masyarakat Desa Cigelam selain diberikan pengetahuan dan motivasi tentang berwirausaha dilatih pula untuk mengolah bayam menjadi rempeyek sehingga memiliki 
nilai jual lebih tinggi. Pada kegiatan pelatihan ini di demostrasikan cara membuat rempeyek bayam.

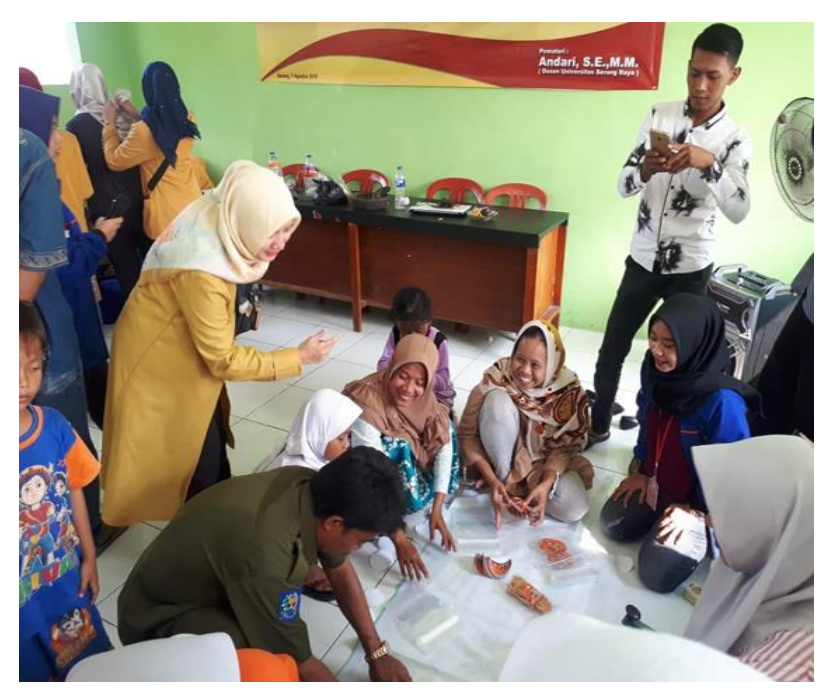

\section{Gambar 5. Kegiatan pembuatan rempeyek bayam}

\section{Pengemasan Produk}

Untuk menarik perhatian calon konsumen pengemasan produk juga merupakan hal yang sangat penting. Tujuannya adalah untuk menjaga nilai kebersihan dan higienitas produk, memiliki nilai estetika agar produk lebih menarik. Produk rempeyek bayam dikemas dengan menggunakan kemasan plastik yang kedap udara sehingga produk akan tahan lama. Selain itu untuk mengenalkan asal produk maka diberikan merek produk yaitu rempeyek "Gelem Peyek", yang artinya rempeyek dari Desa Cigelam.

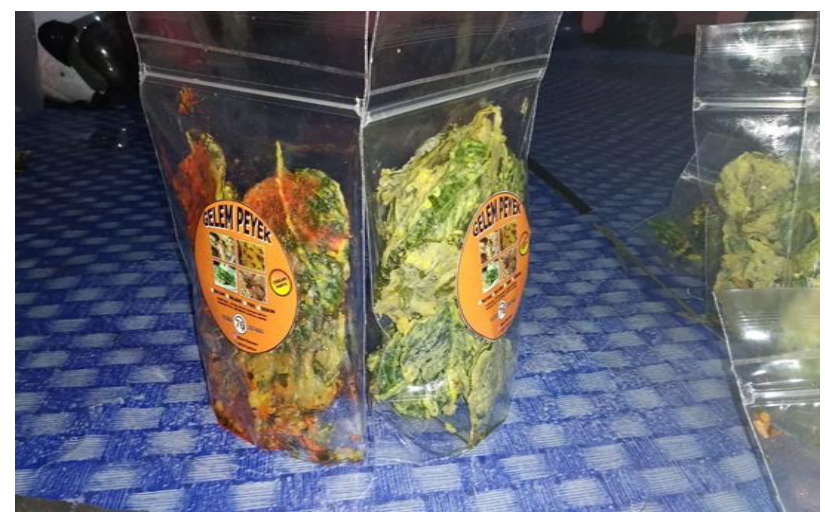

\section{Gambar 6. Produk Rempeyek bayam dengan Merek "Gelem Peyek"}

\section{Pemasaran}

Langkah awal dalam melakukan pemasaran produk yang telah dihasilkan, dipasarkan dengan cara melakukan kerjasama antara warung dan toko-toko yang berada di sekitar Desa Cigelam, dengan tujuan untuk memperkenalkan terlebih dari pedagang eceran.

\section{Target Capaian}

Target capaian produk yang diraih adalah sebagai berikut:

1. Menciptakan lapangan pekerjaan bagi masyarakat khususnya Desa Cigelam dan lingkungan sekitar, dengan membuat kelompok usaha ataupun secara mandiri.

2. Meningkatkan kemampuan berwirausaha sehingga dapat meningkatkan taraf hidup masyarakat yang lebih baik dari sebelumnya melalui seminar, workshop ataupun pelatihan-pelatihan baik formal ataupun non formal.

3. Meningkatkan keterampilan masyarakat agar dapat menciptakan lahan pekerjaan yang baru.

4. Meningkatkan pendapatan masyarakat dengan memanfaatkan potensi desa.

5. Dapat terciptanya kelompok-kelompok usaha yang dapat dijadikan rolemodel bagi masyarakat lainnya dan dapat bekerjasama dengan pemerintah terkait seperti Dinas Koperasi dan UMKM Kabupaten dan Provinsi.

\section{Ucapan Terima Kasih}

Ucapan terima kasih kami sampaikan kepada pihak-pihak terkait:

1. Rektor Universitas Serang Raya yang telah memberikan ijin untuk 
melaksanakan kegiatan pengabdian masyarakat ini.

2. Dekan Fakultas Ekonomi dan Bisnis yang telah memberikan ijin dan dukungan dalam pelaksanaan kegiatan pengabdian masyarakat.

3. Ketua LPPM dan Kabag Pengabdian Masyarakat Universitas Serang Raya Kepada Rektor Universitas Serang Raya dan Dekan Fakultas Ekonomi dan Bisnis

4. Kepala Desa Cigelam beserta jajarannya yang telah memberikan ijin dan dukungan sehingga kegiatan ini dapat berjalan dengan baik.

5. Masyarakat Desa Cigelam atas partisipasi, antusiasme yang tinggi dan semangatnya untuk mengikuti kegiatan pengabdian ini.

\section{KESIMPULAN DAN SARAN}

\section{Kesimpulan}

Kemiskinan merupakan salah satu masalah dalam perekonomian yang harus kita pecahkan bersama. Saat ini pemerintah terus menggencarkan gerakan kewirausahaan untuk mengatasi masalah kemiskinan dan pengangguran khususnya warga desa Cigelam yang mayoritas keadaan ekonomi masyarakatnya masih ditingkat menengah kebawah. Kewirausahaan merupakan faktor penting dalam meningkatkan perekonomian masyarakat. Dengan diadakannya seminar kewirausahaan serta pelatihan pembuatan rempeyek bayam bagi masyarakat desa cigelam diharapkan dapat menciptakan lapangan pekerjaan, meningkatkan keterampilan masyarakat, meningkatkan kemampuan berwirausaha serta meningkatkan pendapatan masyarakat dengan memanfaatkan potensi desa.

\section{Saran}

Menjadi seorang wirausaha merupakan salah satu solusi dari permasalahan yang dialami warga Desa Cigelam. Dengan menjadi wirausaha diharapkan akan menciptakan lapangan pekerjaan yang dapat meningkatkan pendapatan masyarakat Desa Cigelam.

\section{DAFTAR REFERENSI}

Alma, Buchari. (2009). Kewirausahaan. Bnadung : Alfabet.

Ernani Hadiyati. (2012). Kreativitas dan Inovasi Pengaruhnya Terhadap Pemasaran Kewirausahaan Pada Usaha Kecil. Jurnal Inovasi dan Kewirausahaan Volume 1 No. 3 Hal. 135-151 135. Malang : Universitas Gajayana

Hisrich, R. (2001). Entrepreneurship kewirausahaan. Jakarta : Salemba Empat

Indah, Mustikawati, dkk. (2012). Pelatihan Kewirausahaan Bagi Santri Pesantren Darus Shalihat Sebagai Upaya Menumbuhkan Jiwa Kewirausahaan Dan Menggali Ide Usaha Baru.

Rosmiati, dkk. (2015). Sikap Motivasi dan Minat Berwirausaha Mahasiswa. Politeknik Negeri Kupang Jurusan Akuntansi. JMK, VOL. 17, NO. 1, MARET 2015, 21-30 DOI: 10.9744/jmk.17.1.21-30 ISSN 1411-1438 print / ISSN 2338-8234 online.

Wahyu, Suparyanto. (2005). Petunjuk Untuk Memulai Berwirausaha. Bandung : Alfabet 